\title{
sciendo
}

\section{EFFECT OF AGE AT FIRST CALVING ON FIRST LACTATION MILK YIELD, LIFETIME MILK PRODUCTION AND LONGEVITY OF COWS}

\author{
Anna Sawa, Kamil Siatka, Sylwia Krężel-Czopek* \\ Department of Cattle Breeding, UTP University of Science and Technology, \\ Mazowiecka 28, 85-084 Bydgoszcz, Poland \\ •Corresponding author: krezel@utp.edu.pl
}

\begin{abstract}
The objective of the study was to analyse the effect of age at first calving (AFC) on first lactation milk yield, lifetime milk production and longevity of dairy cows. The study used SYMLEK data on the milk yield and culling of 111857 Polish Holstein-Friesian cows from the active population in Pomerania and Kujawy, Poland. The cows first calved during 2000-2009 and were used or removed from the herds until the end of 2015. For each cow, calculations were made of first lactation milk yield, lifetime milk production, first lactation milk yield per milking day, lifetime milk production per day, as well as the lifespan (length of productive life, duration of rearing) and number of calvings. Based on the age at first calving (duration of the rearing period), the cows were grouped as follows: $\leq 22,22.1-24.0,24.1-26.0,26.1-28.0,28.1-30.0,30.1-32.0$ and $>32$ months. The GLM, CORR PEARSON and FREQ procedures from the SAS package were used in the statistical calculations. Considering first lactation milk yield, lifetime milk production and longevity, it is recommended that the cows should be first milked between 22.1 and 26.0 months of age. This is supported by the approximately $24 \%$ higher lifetime milk production in relation to the latest calving cows $(\mathrm{P}<\mathbf{0 . 0 1})$. Late commencement of the first milking (especially after 28 months) causes a considerable decrease in the first lactation milk yield and lifetime milk production, shortens the productive period, reduces the number of calvings, and increases culling rate due to low milk yield and udder diseases.
\end{abstract}

Key words: age at first calving, longevity, lifetime milk production

The age at first calving, the lifespan and the length of productive life have an effect on genetic progress and economic performance of dairy cows (Dákay et al., 2006; Wathes et al., 2008; Teke and Murat, 2013; Caetano et al., 2017; Cielava et al., 2017). The age of cows at first milking is particularly important as it affects fertility, course of parturition, milk yield and length of productive life (Cooke et al., 2013; 
Zavadilová and Štipková, 2013). Although the natural lifespan of a cow can exceed 15-20 years and the world's oldest cow lived to the ripe old age of 35 years (Cielava et al., 2017; Sawa and Bogucki, 2010), cows in modern farms are on average culled at the age of 4.5-6.6 years (Cielava et al., 2017).

The age at first calving can be considered as a trait specific to a cow population; for example, for the Holstein-Friesian breed it is 25 months in Ireland, 24-26 months in Great Britain, 26 months in the Czech Republic, $\leq 25-27$ months in the USA and 28 months in Italy (Cooke et al., 2013; Sitkowska et al., 2015). In the case of Holstein-Friesian cattle, $\leq 24$ months is considered the optimal age at first calving to maximize production and to minimize the costs of rearing heifers (Krpalkova et al., 2017; Olechnowicz et al., 2016; Zavadilová and Štipková, 2013), although 21-25 months (Boulton et al., 2015; Cooke et al., 2013; Gavan et al., 2014) and 23-24.5 months (Cooke et al., 2013; Curran et al., 2013; Vacek et al., 2015) have also been suggested. American analyses of heifer rearing costs show that each month of delay costs an additional \$50-75 (Hutchison et al., 2017; Penev et al., 2014). In turn, British analyses (Boulton et al., 2015) suggest that delaying age at first calving in relation to the optimal date increases average rearing costs by 0.33 pound per day. On the other hand, advancing the date of first calving to the age of 23 months may reduce milk yield by $310 \mathrm{~kg}$, and to the age of $<24$ month may decrease first lactation milk yield by $0.6 \mathrm{~kg} /$ day (Mohd et al., 2013). Other studies (Nilforooshan and Edriss, 2004; Teke and Murat 2013) show that when milk production begins too early ( $\leq 22$ months of age) or too late ( $>30$ months of age), the lifespan of cows is considerably shortened and the culling rates increase due to low milk production and udder diseases. The potential benefits of shortening the heifer rearing period include an increase in the number of calves born throughout life (Gavan et al., 2014), sale of heifers for herd replacement (Cooke et al., 2013), an increase in genetic progress as a result of shortened generation interval, and earlier progeny testing of bulls (Gavan et al., 2014; Penev et al., 2014). It has also been reported that age at first calving has no effect on lifetime productivity of the cows if it ranges between 22 and 32 months (Curran et al., 2013).

At present, cows do not often die naturally because they are culled earlier for infertility, claw disease, or mastitis among others (Ahlman et al., 2011; Langford and Stott, 2012; Pritchard et al., 2013; Caetano et al., 2017; Olechnowicz, 2016). According to Brickell et al. (2009), many cows (14-19\%) are already selected during the first lactation and poor fertility is the main reason for culling primiparous cows.

The inconsistent results of the studies performed in different countries and the interest of breeders in functional traits, including longevity have prompted us to perform analyses aimed at improving the production efficiency of dairy cows. The objective of the study was to analyse the effect of age at first calving (AFC) on first lactation milk yield, lifetime milk production and longevity of dairy cows, based on extensive material obtained from performance testing of cows in the KujawskoPomorskie province (around 10\% of the national population of performance-tested cows in Poland). 


\section{Material and methods}

The study was performed based on information from the SYMLEK database concerning the milk yield and culling of 111857 Black-and-White Polish Holstein-Friesian cows from the active population in Pomerania and Kujawy, Poland. The cows first calved during 2000-2009 and were used or removed from the herds until the end of 2015. For each cow, calculations were made of first lactation milk yield, lifetime milk production, first lactation milk yield per milking day, lifetime milk production per day of milking, as well as the lifespan (date of culling - date of birth)/365 (years), length of productive life (date of culling - date of the first calving)/365 (years) and number of calvings. Based on the age at first calving (duration of the rearing period), the cows were grouped as follows: $\leq 22,22.1-24.0,24.1-26.0,26.1-28.0,28.1-30.0$, $30.1-32.0$ and $>32$ months.

Using analysis of variance, the effect of age at first calving on first lactation milk yield, lifetime milk production and longevity of cows was determined with the least squares means method (SAS, 2014), and the differences between the means for different traits within the age at first calving groups were estimated with the Scheffe test.

The CORR PEARSON procedure (SAS, 2014) was used to calculate the coefficients of simple correlation between age at first calving and first lactation milk yield, lifetime milk production and longevity.

The One-Way Frequencies procedure and Chi-square independence test (SAS, 2014) were used to analyse the proportion of cows surviving to the second calving and cows removed due to low milk yield, udder diseases, infertility and reproductive diseases, digestive diseases, infectious diseases (including leucosis), old age, metabolic and gastrointestinal diseases, respiratory diseases, locomotor system diseases, accidents, or cows that lived until the end of 2015.

\section{Results}

The least cows $(2.1 \%)$ calved before reaching the age of 22 months. The proportion of cows that first calved at the age of 24.1-26.0 and 26.1-28.0 months was considerable (30.7\% and $22.4 \%$, respectively). Age at first calving greater than 30 months was reached by $9.1 \%$ of the cows (Table 1 ).

The age of cows at first calving caused differences $(\mathrm{P}<0.01)$ in their subsequent milk yields and longevity (Tables 1 and 2). Considering first lactation milk yield, commencement of milking before 22 months of age proved least beneficial, while extension of the rearing period to 28 months contributed to increases in lactational and daily yield. Only after 28 months a significant decrease in milk yield is seen (Table 1). It must be stressed, however, that it seems justifiable to extend the rearing period to 28 months of age at most. Heifers calving at an older age had a higher lactational and daily yield in the first production cycle compared to their peers that calved before reaching the age of 22 months, but their advantage decreased as rearing period increased from $11.3 \%$ (26.1-28 months) to $1.0 \%$ (>32 months). 
A. Sawa et al.

Table 1. Milk performance of primiparous cows depending on age at first calving

\begin{tabular}{|c|c|c|c|c|c|}
\hline \multirow{2}{*}{\multicolumn{2}{|c|}{$\begin{array}{l}\text { Age at first calving } \\
\text { (months) }\end{array}$}} & \multirow{2}{*}{$\begin{array}{l}\text { Number } \\
\text { of cows }\end{array}$} & \multicolumn{2}{|c|}{ Milk yield (kg) } & \multirow{2}{*}{ Milking days } \\
\hline & & & lactation milk yield & daily milk yield & \\
\hline$\leq 22$ & 1 & 2350 & 6504 & 18.1 & 358 \\
\hline $22.1-24$ & 2 & 16121 & 7032 & 19.6 & 358 \\
\hline $24.1-26$ & 3 & 34317 & 7303 & 20.4 & 359 \\
\hline $26.1-28$ & 4 & 25085 & 7364 & 20.4 & 361 \\
\hline $28.1-30$ & 5 & 14984 & 7271 & 19.9 & 364 \\
\hline $30.1-32$ & 6 & 8817 & 7086 & 19.5 & 363 \\
\hline$>32$ & 7 & 10183 & 6766 & 18.7 & 361 \\
\hline \multicolumn{6}{|c|}{ Significance of differences } \\
\hline & & & $\begin{array}{l}1-2,3,4,5,6^{\mathrm{xx}}, 7^{\mathrm{x}} \\
2-3,4,5,7^{\mathrm{xx}} \\
3-6,7^{\mathrm{xx}} \\
4-6,7^{\mathrm{xx}} \\
5-6,7^{\mathrm{xx}} \\
6-7^{\mathrm{xx}}\end{array}$ & $\begin{array}{l}1-2,3,4,5,6,7^{\mathrm{xx}} \\
2-3,4,5,7^{\mathrm{xx}} \\
3-5,6,7^{\mathrm{xx}} \\
4-5,6,7^{\mathrm{xx}} \\
5-6,7^{\mathrm{xx}} \\
6-7^{\mathrm{xx}}\end{array}$ & $\begin{array}{l}2-5^{x x} \\
3-5^{x}\end{array}$ \\
\hline
\end{tabular}

${ }^{x x}(\mathrm{P}<0.01), \quad{ }^{x}(\mathrm{P}<0.05)$.

Table 2. Effect of age at first calving on survival of cows to the second calving

\begin{tabular}{l|c|c|c}
\hline \multirow{2}{*}{$\begin{array}{c}\text { Age at first calving } \\
\text { (months) }\end{array}$} & \multirow{2}{*}{$\begin{array}{c}\text { Number of } \\
\text { cows }\end{array}$} & \multicolumn{2}{|c}{$\begin{array}{c}\text { Share of cows (\%) } \\
\text { Chi }^{2}=544^{\mathrm{xx}}\end{array}$} \\
\cline { 3 - 4 } & & $\begin{array}{c}\text { removed from the herd } \\
\text { in the first production cycle }\end{array}$ & second calving \\
\hline$\leq 22$ & 2350 & 18.94 & 81.06 \\
$22.1-24$ & 16121 & 17.78 & 82.22 \\
$24.1-26$ & 34317 & 18.93 & 81.07 \\
$26.1-28$ & 25085 & 20.70 & 79.30 \\
$28.1-30$ & 14984 & 22.34 & 77.66 \\
$30.1-32$ & 8817 & 23.39 & 76.61 \\
$>32$ & 10183 & 27.99 & 72.01 \\
Total & 111857 & 20.80 & 79.20 \\
\hline
\end{tabular}

${ }^{\mathrm{xx}}(\mathrm{P}<0.01)$.

The proportion of cows that calved twice averaged $79.2 \%$ (Table 2 ). The best prospects of survival to the second calving $(82.22 \%)$ was found in the cows which were first milked at 22.1-24 months. Delaying the beginning of first milking to the age of 32 months caused a gradual decrease in the proportion of cows surviving to the second calving, whereas the $>32$ months group had a considerable proportion $(27.99 \%)$ of cows removed from the herd in the first production cycle.

The highest lifetime yield (more than $25000 \mathrm{~kg}$ milk) was reached by the cows which first calved at the age of 22.1-26 months (Table 3). Cows that were first milked at a later date, (especially after 28 months of age) exhibited considerably lower milk yields (by as much as $6000 \mathrm{~kg}$ in the $>32$ months group). The cows that first calved at the age of 22.1-26 months had an approximately 5\% higher lifetime 
yield in relation to those that calved the earliest and an approximately $24 \%$ higher lifetime yield compared to the cows that calved the latest $(\mathrm{P}<0.01)$. A very weak correlation was shown between age at first calving and lifespan $\left(\mathrm{r}=0.062^{* *}\right)$ (Table 4). It should be noted that the longer lifespan resulted from the longer rearing period and not from the longer productive life. The productive period, which is becoming of importance for selection in the leading dairy farms around the world, was the longest (3.54 years) in the group of cows that first calved at the age of 22.1-24.0 months. In the other groups, there was a tendency to a shorter productive period ranging from 3.49 years with an earlier first calving to 2.94 years with increasing age at first calving. Also, the number of days in lactation per lifetime was highest for the cows that first calved between 22.1 and 24.0 months of age.

Table 3. Lifetime milk yield of the cows and their longevity depending on the age at first calving

\begin{tabular}{|c|c|c|c|c|c|c|c|}
\hline \multirow{2}{*}{\multicolumn{2}{|c|}{$\begin{array}{l}\text { Age at first } \\
\text { calving } \\
\text { (months) }\end{array}$}} & \multicolumn{2}{|c|}{ Milk yield (kg) } & \multirow[b]{2}{*}{$\begin{array}{l}\text { Lifespan } \\
\text { (years) }\end{array}$} & \multirow[b]{2}{*}{$\begin{array}{c}\text { Length } \\
\text { of productive } \\
\text { life (years) }\end{array}$} & \multirow{2}{*}{$\begin{array}{l}\text { Lifetime } \\
\text { number } \\
\text { of milking } \\
\text { days }\end{array}$} & \multirow[b]{2}{*}{$\begin{array}{l}\text { Number } \\
\text { of calvings }\end{array}$} \\
\hline & & $\begin{array}{l}\text { lifetime } \\
\text { milk } \\
\text { yield }\end{array}$ & $\begin{array}{l}\text { lifetime milk } \\
\text { yield per day } \\
\text { of milking }\end{array}$ & & & & \\
\hline$\leq 22$ & 1 & 23854 & 20.0 & 5.24 & 3.49 & 1149 & 3.36 \\
\hline $22.1-24$ & 2 & 25099 & 21.3 & 5.49 & 3.54 & 1153 & 3.36 \\
\hline $24.1-26$ & 3 & 25053 & 21.9 & 5.52 & 3.44 & 1120 & 3.25 \\
\hline $26.1-28$ & 4 & 23773 & 21.7 & 5.52 & 3.20 & 1070 & 3.10 \\
\hline $28.1-30$ & 5 & 22573 & 21.1 & 5.65 & 3.23 & 1047 & 3.02 \\
\hline $30.1-32$ & 6 & 21389 & 20.5 & 5.73 & 3.15 & 1016 & 2.94 \\
\hline$>32$ & 7 & 19095 & 19.5 & 5.87 & 2.94 & 949 & 2.75 \\
\hline \multicolumn{8}{|c|}{ Significance of differences } \\
\hline & & $1-6,7^{x x}$ & $1-2,3,4,5^{\mathrm{xx}}, 7^{\mathrm{x}}$ & $1-2,3,4,5,6,7^{x x}$ & $1-4^{\times}, 5,6,7^{\mathrm{xx}}$ & $1-4,5,6,7^{\mathrm{xx}}$ & $1-4,5,6,7^{\mathrm{xx}}$ \\
\hline & & $2-4,5,6,7^{x x}$ & $2-3,4,6,7^{\mathrm{xx}}$ & $2-5,6,7^{x x}$ & $2-3,4,5,6,7^{x x}$ & $2-3,4,5,6,7^{x x}$ & $2-3,4,5,6,7^{x x}$ \\
\hline & & $3-4,5,6,7^{\mathrm{xx}}$ & $3-4,5,6,7^{\mathrm{xx}}$ & $3-5,6,7^{x x}$ & $3-4,5,6,7^{x x}$ & $4-6,7^{x x}$ & $3-4,5,6,7^{x x}$ \\
\hline & & $4-5,6,7^{\mathrm{xx}}$ & $4-5,6,7^{x x}$ & $4-5,6,7^{\mathrm{xx}}$ & $4-6,7^{x x}$ & $5-7^{x x}$ & $4-5,6,7^{\mathrm{xx}}$ \\
\hline & & $5-6,7^{x x}$ & $5-6,7^{x x}$ & $5-7^{x x}$ & $5-7^{x x}$ & $6-7^{x x}$ & $5-7^{x x}$ \\
\hline & & $6-7^{x x}$ & $6-7^{x x}$ & $6-7^{x x}$ & $6-7^{x x}$ & & $6-7^{x x}$ \\
\hline
\end{tabular}

${ }^{x x}(\mathrm{P}<0.01),{ }^{x}(\mathrm{P}<0.05)$.

Table 4. Coefficients of correlation between age of cows at first calving and their milk yield and longevity

\begin{tabular}{lc}
\hline \multicolumn{1}{c}{ Trait } & $\mathrm{r}$ \\
\hline First lactation milk yield (kg) & $-0.02322^{\mathrm{xx}}$ \\
Milking days in the first lactation & $0.01191^{\mathrm{xx}}$ \\
First lactation daily milk yield (kg) & $-0.04876^{\mathrm{xx}}$ \\
Lifetime milk production (kg) & $-0.11123^{\mathrm{xx}}$ \\
Lifetime milk production per day (kg) & $-0.09383^{\mathrm{xx}}$ \\
Lifespan (years) & $0.06232^{\mathrm{xx}}$ \\
Length of productive life (years) & $-0.08125^{\mathrm{xx}}$ \\
Lifetime number of milking days & $-0.08841^{\mathrm{xx}}$ \\
Number of calvings & $-0.09868^{\mathrm{xx}}$ \\
\hline
\end{tabular}







Negative but low correlations $\left(-0.11^{* *}--0.09^{* *}\right)$ were observed between age at first calving and lifetime yield and the yield per milking day (Table 4). This shows that a higher lifetime milk yield can be expected in animals calving at a younger age.

Considering the number of calvings, calving at the age of more than 28 months was highly unfavourable (Table 3 ). The cows that first calved at the age of $\leq 22$ and 22.1-24.0 months, gave birth to more calves during their lives than cows from the other groups (e.g., by 0.6 calf more than in the $>32$ months group). The correlation between age at first calving and number of calvings $\left(r=-0.099^{* *}\right)$ was low but statistically significant (Table 4).

The age at first calving had a statistically significant effect on the percentage of cows removed from herds $\left(\mathrm{chi}^{2}=782^{* *}\right)$ (Table 5). The proportion of cows sold for further breeding was $12.17 \%$ for those born as the youngest and $8.30 \%$ for those born the oldest. Regardless of the age at first calving, the main reasons for culling were infertility and reproductive diseases $(35.75 \%)$. The highest proportion $(37.01 \%)$ of cows culled for that reason occurred in the group that first calved at the age of 22.1-24 months, and the lowest (32.55\%) in the $\leq 22$ months group. The next reasons for culling were accidents $(14.92 \%)$ and udder diseases $(12.86 \%)$. For these two culling reasons, there was a tendency for the proportion of culled cows to increase with increasing rearing period. The average proportion of cows culled for low milk yield $(2.12 \%)$ is considerably low. The lowest proportion $(1.58 \%)$ occurred for the cows that first calved at the age of 22.1-24 and 24.1-26.0 months, and it increased to approximately $2.21 \%$ and $2.94 \%$ when the rearing period was shortened and increased, respectively.

\section{Discussion}

The effect of age at first calving on the milk yield of primiparous cows, as observed in the present study, supports the findings of Sitkowska et al. (2015), who noted milk yield during the first 100 days of lactation to be highest in cows older than 26 months when first milked, and lowest in cows less than 23 months old when first milked. A negative effect of advancing the date of first milking on 305-day milk yield was reported in a Dutch study (Mohd et al., 2013). Cows that first calved at the age of 24 months had a milk yield of $7164 \mathrm{~kg}$, those calving 1 month earlier produced $143 \mathrm{~kg}$ less milk. Likewise, Bayram et al. (2009), Salazar-Carranza et al. (2014) and Hutchison et al. (2017) reported first lactation milk yield to increase by around $1000 \mathrm{~kg}$ when the age of first calving was increased from 21 to 32 months. In turn, Shindarska et al. (2016) obtained the highest first lactation milk yield in cows that calved at 24 months, whereas the yields of cows that calved at an older age were lower. Similarly, Vacek et al. (2015), who analysed the influence of heifer rearing intensity on milk yield in the first three lactations, showed that animals with higher daily gains during the rearing period were the first to be milked ( 714 days) and achieved the highest first lactation milk yield, while postponing the date of first calving resulted in lower first lactation milk yield. Also Haworth et al. (2008) dem- 
onstrated lower milk yield of primiparous cows when they first calved at the age of 2.5 years and later, in relation to those that had their first offspring at a younger age. In turn, Curran et al. (2013) concluded that age at first calving between 23 and 30 months did not cause differences in the milk yield of primiparous cows, and that calvings between 20 and 22 months reduced the milk yield. Also Cooke et al. (2013) were not able to show a significant effect of age at first calving on the milk yield of primiparous cows. Teke and Murat (2013) suggest that the effect of age at first calving on first lactation milk yield is not significant $(\mathrm{P}>0.05)$, in contrast to lifetime milk yield, which was highest when the cows first calved at 23 months old.

The effect of age at first calving on survival, which we analysed in the present study, was also evaluated by Gavan et al. (2014), who found that among cows with age at first calving less than 24 months, $71.4 \%$ produced their second offspring and $42.8 \%$ calved three times. In the group of cows with age at first calving of $25-27$ months, $86.7 \%$ of the cows survived to the second lactation, and $75.6 \%$ to the third. Primiparous cows that calved between 28 and 30 months of age survived to the second and third lactation in $84.2 \%$ and $68.4 \%$ of the cases, respectively. In the case of cows that first calved when older than 30 months, only $44.4 \%$ calved three times. According to Cooke et al. (2013), the group of cows that first calved as the youngest ( $<26$ months) achieved a higher survival rate; also Evans et al. (2006) showed the highest survival rate for cows that first calved at the age of 25-26 months.

The possibility of increasing the productive life of the cows is of particular interest for breeders. In the present study, the longest productive life (3.54 years) was characteristic of the cows that first calved at the age of 22.1-24.0 months, and in the other groups the productive life decreased to 3.49 years (with advanced age of first calving) or to 2.94 years (with delayed age of first calving). Similar trends for shortened productive lives were reported by Sawa and Bogucki (2010) and Jankowska et al. (2014). Also the lifetime number of milking days was greatest for cows that first calved between 22.1 and 24.0 months, which corresponds with the results obtained in the Czech Republic which suggested that productive lives of the cows decreased as a result of delayed first calving (Zavadilová and Štipková, 2013). Also Olechnowicz et al. (2016) reported a trend for a decrease in the productive life of the cows that first calved at an older age. According to Cielava et al. (2017), the age of first calving has a significant effect on the lifespan of the cows, and in their study the difference between the lifespan of the cows that first calved at $<24$ and $>30$ months was 1.4 years at the beginning of fifth lactation (5.9 vs 7.3 years). In turn, Adamczyk et al. (2017) reported that productive life of the cows that first calved before 24 months decreased compared to those that first calved $>31$ months, from 5.9 to 5.4 years. This appears to be confirmed by Do et al. (2013), who showed a positive, low correlation between age at first calving and the lifetime number of milking days $(r=0.084)$. Different results were reported by Haworth et al. (2008) for Australian Holstein cattle; they found a significant decrease in the productive life of the cows that first calved at the age of $<2$ years and a significant increase in the productive life of the cows that first calved when $>3$ years old. In turn, Krpalkova et al. (2017) provided evidence that age at first calving ( $\leq 749,750-799, \geq 800$ days) had no significant effect on the number of lactations, which ranged from 2.38 to 2.45 . The lack of a conclusive ef- 
fect of the age at first calving on longevity was reported by Cooke et al. (2013) for two groups of cows; in the first group, the optimum age at first calving to obtain long-lived cows (reaching 5 years of age/third lactation) was $<23$ months ( $86 \%$ ), followed by 23-25 months (62\%), 26-30 months (41\%) and >30 months (33\%), and in the second group the proportion of cows surviving to the above period was $55-64 \%$ (a higher percentage was observed for cows that calved at a later date) and showed no significant differences.

Correlation between age at first calving and lifespan was positive and low $\left(\mathrm{r}=0.062^{* *}\right)$ (Table 4). Similarly low $(0.039-0.061)$ but significant coefficients of correlation were previously reported by Sawa and Bogucki (2010) and Do et al. (2013) $(\mathrm{r}=0.0131)$.

The present study showed that age at first calving had an impact on lifetime milk yield. Our results agree with those of Hutchison et al. (2017) and Adamczyk et al. (2017), who found that highest lifetime yield (25 $184 \mathrm{~kg}$ ECM) can be expected from cows that first calve up to 2 years of age, and lowest lifetime yield in cows older than 2.6 years (20 $783 \mathrm{~kg}$ ECM). Similar trends were reported by Sitkowska et al. (2015), who showed significantly higher lifetime yield for cows that first calved at the age of $<25-28$ months (over $31000 \mathrm{~kg}$ ) in relation to those that calved at $>28$ months of age (around $27800 \mathrm{~kg}$ ). Also Jankowska et al. (2014) considered the age of 22.1-24 months to be optimal for first calving from the viewpoint of the cows' lifetime yield. In turn, Curran et al. (2013) demonstrated that in high-yielding cows $(\geq 11$ $250 \mathrm{~kg}$ for a 365-day lactation), first calvings at 20-23 months of age increase the length of the productive life in relation to those calving at the age of 24 months. Also Olechnowicz et al. (2016), based on a review of the literature, showed that moving the date of first calving beyond 24.5 months of age adversely affects the cow's lifetime performance. Likewise, Cooke et al. (2013) noted the highest milk yields for a total of five lactations in cows that first calved at the age of 23-25 months, and significantly lower yields in cows that first calved $>30$ months of age. Different results were presented by Haworth et al. (2008), who obtained the highest lifetime yields for cows that first calved at the age of $2-2.5$ and $>3$ years. In turn, Dákay et al. (2006) showed that cows first calving between 27 and 30 months of age achieved the highest lifetime milk yield (49330 kg).

Considering the number of calvings, calving at an age older than 28 months was highly unfavourable (Table 3). Also an earlier report (Sawa and Bogucki, 2010) indicates that first calving at a younger age contributes to a greater number of offspring. According to Haworth et al. (2008), the number of calvings during the cows' lifetime was not significantly associated with the age at first calving. Cooke et al. (2013) reported the highest periparturient mortality $(23 \%)$ in cows that first calved before 23 months of age.

Reasons for culling cows are important from breeding and economic perspectives. The findings of Krpalkova et al. (2017) show a tendency, similar to that reported in our study, that later age at first calving was associated with a significant increase in the proportion of cows culled from the herd (from 26.9 with AFC $\leq 749$ days to 31.3 with $A F C \geq 800$ days). Strapakova et al. (2014) considered the age at first calving as a factor significantly influencing the rate at which cows are culled 
from the herd (shortened productive life). In our study, regardless of the age of cows at first calving, the main reasons for culling were infertility and reproductive diseases (35.75\%). Likewise, based on an analysis of literature data, Cooke et al. (2013) listed reproductive problems as the most frequent (14-19\%) reason for culling first calvers from the herd. The results that show reproductive problems as the most common reason for culling the cows and the reports that reasons such as low yield and old age are of minor importance, correspond with the findings of other authors (Gavan et al., 2014; Jankowska et al., 2014).

It is worth mentioning the results of studies by Curran et al. (2013), Do et al. (2013) and Krpalkova et al. (2017), who concluded that because of different herd management strategies, it is difficult to pinpoint one single and optimal moment for the first milking of cows.

\section{Conclusion}

In summary, it is concluded that considering the first lactation milk yield, lifetime milk production and longevity, it is recommended that the cows should be first milked between 22.1 and 26.0 months of age. This is supported by the approximately $24 \%$ higher lifetime milk production in relation to the latest calving cows $(\mathrm{P}<0.01)$. Late commencement of the first milking (especially after 28 months) causes a considerable decrease in the first lactation milk yield and lifetime milk production, shortens the productive period, reduces the number of calvings, and increases culling rates due to low milk yield and udder diseases.

\section{References}

A damczyk K., Makulska J., Jagusiak W., Węglarz A. (2017). Associations between strain, herd size, age at first calving, culling reason and lifetime performance characteristics in Holstein-Friesian cows. Animal, 11: 327-334.

A hlman T., B erglund B., Rydhmer L., Strandberg E. (2011). Culling reasons in organic and conventional dairy herds and genotype by environment interaction for longevity. J. Dairy Sci., 94: $1568-1575$.

B a y r a m B., Yan a r M., A k bu l u t O. (2009). The effect of average daily gain and age at first calving on reproductive and milk production traits of Brown Swiss and Holstein Friesian cattle. Bulg. J. Agric. Sci., 15: 453-462.

B oult on A.C., Rushton J., Wathes D.C. (2015). Analysis of the management and costs associated with rearing pregnant dairy heifers in the UK from conception to calving. Open J. Anim. Sci., 5: 474-485.

B ri ckell J.S., M c G ow an M.M., P fe iffer D.U., Wa the s D.C. (2009). Mortality in HolsteinFriesian calves and replacement heifers in relation to body weight and IGF-I concentration, on 19 farms in England. Animal, 3: 1175-1182.

Caetano S.L, Rosa G.J., S avegnago R.P., Ramos S.B., B ernardes P.A., B ezz er a L.A., L ôbo R.B., d e P a z C.C., Munari D.P. (2017). Estimation of genetic parameters for longevity considering the cow's age at last calving. J. Appl. Genetics, 58: 103-109.

C i e l a v a L., J o n k u s D., P a u r a L. (2017). The effect of cow reproductive traits on lifetime productivity and longevity. World Academy of Science, Engineering and Technology, International Science Index 123, International Journal of Biological, Biomolecular, Agricultural, Food and Biotechnological Engineering, 11: 220-223.

C o oke J.S., Cheng Z., B ourne N.E., Wathes D.C. (2013). Association between growth rates, 
age at first calving and subsequent fertility, milk production and survival in Holstein-Friesian heifers, Open J. Anim. Sci., 3: 1-12.

Curran R.D., Weigel K.A., Hoffman P.C., Marshall J.A., Kuzdas C.K., Coble n t z W.K. (2013). Relationships between age at first calving; herd management criteria; and lifetime milk, fat, and protein production in Holstein cattle. The Professional Animal Scientist, 29: 1-9.

Dáka y I., Márton D., K e ll e r K., F ördö s A., T örök M., S z a b ó F. (2006). Study on the age at first calving and the longevity of beef cows. J. Cent. Eur. Agric., 7: 377-388.

Do C., Was an a N., Cho K., Choi Y., Choi T., P ark B., L e e D. (2013). The effect of age at first calving and calving interval on productive life and lifetime profit in Korean Holstein. AsianAustralas. J. Anim. Sci., 26: 1511-1517.

Evan s R.D., Walla c e M., Garrick D.J., Di11 o n P., B erry D. P., O1 ori V. (2006). Effects of calving age, breed fraction and month of calving on calving interval and survival across parties in Irish spring-calving dairy cows. Livest. Sci., 100: 216-230.

G a v a n C., D r a g a n F., M o n t or g a V. (2014). Age of first calving and subsequent fertility and survival in Holstein Friesian cattle. Scientific Papers: Animal Science and Biotechnologies, 47: 37-40.

Haw orth G.M., Tranter W.P., Chu ck J.N., Cheng Z., Wa the s D.C. (2008). Relationships between age at first calving and first lactation milk yield, and lifetime productivity and longevity in dairy cows. Vet. Rec., 162: 643-647.

H u t c h i s o n J.L., Van R a d e n D.J., C o le J.B., B i c khart t D.M. (2017). Genomic evaluation of age at first calving. J. Dairy Sci., 100: 1-9.

Jankowska M., S aw a A., Ku jaw ska J. (2014). Effect of certain factors on the longevity and culling of cows. Acta Sci. Pol., Zootech., 13: 19-30.

Krpalkova L., Syrucek J., Kvapilik J., Burdych J. (2017). Analysis of milk production, age of first calving, calving interval and economic parameters in dairy cattle management. Mljekarstvo, 67: 58-70.

L a n g ford F.M., S t o t t A. W. (2012). Culled early or culled late: economic decisions and risks to welfare in dairy cows. Anim. Welfare, 21: 41-55.

Mohd N., Steeneveld W., van Werven T., Mourits M.C.M., Hogeveen H. (2013). First-calving age and first-lactation milk production on Dutch dairy farms. J. Dairy Sci., 96: 981-992.

Nilfor o o s han M.A., Edris s M.A. (2004). Effect of age at first calving on some productive and longevity traits in Iranian Holsteins of the Isfahan province. J. Dairy Sci., 87: 2130-2135.

O lechnow icz J., Kn eblewski P., Jaśk ow ski J.M., Włodarek K. (2016). Effect of selected factors on longevity in cattle: a review. J. Anim. Plant Sci., 26: 1533-1541.

P e n e v T., Va s i l e v N., S t a n k o v K., M i t e v J., K i r o v V. (2014). Impact of heifers' age at first breeding and first calving on some parameters of economic effectiveness at dairy cattle farms. Int. J. Curr. Microbiol. App. Sci., 3: 772-778.

Pritchard T., Coffey M., Mrode R., Wall E. (2013). Genetic parameters for production, health, fertility and longevity traits in dairy cows. Animal, 7: 33-46.

Salazar-Carranza M., Castillo-Badilla G., Murillo-Herrera J., Hueckmann- Vos s F., Romero-Zuniga J.J. (2014). Effect of age at first calving on first lactation milk yield in Holstein cows from Costa Rican specialized dairy herds. Open Journal of Veterinary Medicine, 4: 197-203.

S a w a A., Bogucki M. (2010). Effect of some factors on cow longevity. Arch. Tierzucht, 53: 403-414.

$\mathrm{S}$ h in d a r s k a Z., P o p o v G., R a l c h e v I. (2016). Influence of age at first calving on milk quantity at Holstein-Friesian cows. Int. J. Curr. Microbiol. App. Sci., 5: 254-259.

S itkowska B., Piwczyński D., La ch Z., Kolenda M. (2015). Relationship between primiparas first 100-days lactation and their lifetime production in Polish Holstein-Friesian Cattle. J. Cent. Eur. Agric., 16: 1-12.

Strapakova E., Strapak P., Candrak J. (2014). Estimation of breeding values for functional productive life in Slovak Holstein population. Czech J. Anim. Sci., 59: 54-60.

Teke B., Murat H. (2013). Effect of age at first calving on first lactation milk yield, lifetime milk yield and lifetime in Turkish Holsteins of the Mediterranean region in Turkey. Bulgarian Journal of Agricultural Science, Agricultural Academy, 19: 1126-1129.

Vacek M., Krpalkova L., Syrucek J., S tipkova M., Janecka M. (2015). Relationships 
between growth and body condition development during the rearing period and performance in the first three lactations in Holstein cows. Czech J. Anim. Sci., 60: 417-425.

Wathes D.C., B rickell J.S., B ourne N.E., S w ali A., Cheng Z. (2008). Factors influencing heifer survival and fertility on commercial dairy farm. Animal, 2: 1135-1143.

Z a v a d i l o vá L., Š t i p k o vá M. (2013). Effect of age at first calving on longevity and fertility traits for Holstein cattle. Czech J. Anim. Sci., 58: 47-57.

Received: 17 V 2018

Accepted: 1 X 2018 